\title{
Penerapan Cara Pembenihan Ikan yang Baik dalam Meningkatkan Kinerja UMKM Pembenihan Udang di Kabupaten Barru, Provinsi Sulawesi Selatan
}

\author{
Application of Good Hatchery Practices To Improve the Performance of SMEs Shrimp Hatchery in \\ Barru District, South Sulawesi Province
}

Fatimah Sau ${ }^{* 1}$, Ma'mun Sarma ${ }^{2+}$, dan Wini Trilaksani ${ }^{3}$

${ }^{1}$ Kementerian Kelautan dan Perikanan

Gedung Mina Bahari IV, Jl. Batu No. 1, Gambir, Jakarta 10110

${ }^{2}$ Departemen Manajemen, Fakultas Ekonomi dan Manajemen, Institut Pertanian Bogor

Jl. Kamper, Kampus IPB Darmaga, Bogor 16680

${ }^{3}$ Departemen Teknologi Hasil Perairan, Fakultas Perikanan dan Ilmu Kelautan IPB

Jl. Lingkar Akademik, Kampus IPB Darmaga, Bogor 16680

\begin{abstract}
ABSTRAK
Udang merupakan salah satu komoditas unggulan sektor perikanan Indonesia karena ekspornya meningkatkan devisa bagi negara. Era globalisasi perdagangan dunia yang penuh dengan persaingan ketat tidak terkecuali dalam usaha pembenihan udang, mutu menjadi kata kunci, sehingga pada setiap unit pembenihan harus dilakukan sertifikasi. Kajian ini bertujuan: (1) mempelajari regulasi terkait Cara Pembenihan Ikan yang Baik (CPIB), (2) menganalisis hubungan penerapan CPIB terhadap kinerja Usaha Mikro Kecil Menengah (UMKM) Pembenihan Udang di Kabupaten Barru, (3) mengukur kinerja UMKM Pembenihan Udang di Kabupaten Barru, dan (4) mengidentifikasi gap penerapan CPIB. Analisis yang digunakan adalah, kebijakan, regresi linear berganda dan kepentingan-kinerja (Importance Performance Analysis). Hasil analisis isi regulasi peraturan terkait CPIB menunjukkan belum adanya peraturan yang mengatur tentang kewajiban pembenih komoditas udang untuk melakukan sertifikasi, agar mutu benihnya terkendali. Hasil analisis regresi linear berganda menunjukkan penerapan CPIB memiliki pengaruh positif terhadap kinerja unit pembenihan udang di Kabupaten Barru, dengan faktor paling memengaruhi kinerja adalah keamanan pangan dan lingkungan. Kinerja yang dinilai paling baik adalah tersedianya perlengkapan produksi yang memadai untuk menunjang kegiatan produksi. Hasil rataan produksi setelah menerapkan prinsip CPIB menunjukkan adanya peningkatan kinerja produksi $19 \%$. Tingkat kesesuaian harapan dan kinerja pada unit pembenihan untuk memenuhi kepuasan pelanggan dan konsistensi penerapan CPIB memiliki nilai gap negatif $-1,18 \%$, seluruh kinerja unit pembenihan belum memenuhi kepuasan pelanggan dan tidak konsisten menerapkan prinsip-prinsip CPIB.
\end{abstract}

Kata kunci: pembenihan udang, regulasi, sertifikasi CPIB

\section{ABSTRACT}

Shrimp is one of the leading commodity of fishery sector in Indonesia because the number of export increasing the foreign exchange for this country. In globalization era, business has fierce competition, so that the quality is a keyword to succeed. Therefore, shrimp hatcheries must be certified. The objectives are to: (1) study the related Good Hatchery Practices (GHP) regulation, (2) Analyze the relationship of application of GHP on shrimp hatchery performances, (3) measure the performance of shrimp hatcheries, (4) identify the Gap of the application of GHP. Content analysis, multiple regression analysis and important-performance analysis (IPA) was used to process the data. Result of content analysis showed that there were no regulation contain the obligation that every farmer must be certified in order to control the seed shrimp quality. Result of multiple regression analysis revealed that the application of GHP had positive impact on shrimp hatchery performances and the most influence factors

\footnotetext{
*) Korespondensi:

Gedung Mina Bahari IV Lt. 5, Jl. Medan Merdeka Timur No. 16, Gambir, Jakarta Pusat;

email: saufatimah@yahoo.co.id
} 
were food safety and environment. Important-performance analysis showed that the best performance was the availability of adequate production equipment. Average production after applied the GHP principles showed that production increased by $19 \%$. Level of concordance between expectation and performance on hatcheries to meet customer satisfaction and consistency of GHP implementation showed a negative gap value by -1.118 , overall performance on hatcheries have not meet customer satisfaction and inconsistent implementing GHP principles.

Key words: GHP certification, regulation, shrimp hatchery

\section{PENDAHULUAN}

Udang merupakan salah satu komoditas unggulan sektor perikanan Indonesia karena ekspornya meningkatkan devisa bagi negara. Berdasarkan data BPS Sulawesi Selatan tahun 2013 ekspor udang Indonesia tahun 2013 mencapai 126.986,9 ton (US\$ 1.346.351,7) atau mengalami kenaikan dibandingkan tahun 2012 sekitar 4.088,1 ton (US\$ 281.091,5). Sementara realisasi ekspor komoditas udang dan ikan di Sulawesi Selatan sepanjang Januari sampai Oktober tahun 2013 mencapai US\$76,1 juta atau susut $11,26 \%$ dibandingkan periode Januari-Oktober tahun 2012 sebesar US $\$ 85,76$ juta (Nour, 2014).

Era globalisasi perdagangan dunia yang penuh dengan persaingan ketat, tidak terkecuali dalam usaha pembenihan udang, mutu menjadi kata kunci. Hal ini berarti bahwa pasar global mensyaratkan adanya jaminan mutu yang mencerminkan tingkat kepercayaan jangka panjang berkesinambungan dan bukan hanya merupakan kesepakatan antara produsen dan konsumen dalam lingkup terbatas.

Permasalahan pada tahun 2010 adalah temuan Uni Eropa mengenai CPIB dan Cara Budidaya Ikan yang Baik (CBIB), yaitu belum adanya persyaratan sertifikasi kedua standar tersebut bagi pembenih dan pembudidaya udang. Pada tahun 2015, Meksiko menghentikan ijin impor udang dari Indonesia karena ditemukan udang vanamei terinfeksi Infectious Myonecrosis Virus (IMNV). Infectious Myonecrosis Virus merupakan salah satu penyakit udang yang masuk dalam daftar virus berbahaya oleh The World Organisation for Animal Health.

Kegiatan usaha budidaya udang saat ini diarahkan untuk dilakukan secara bertanggung jawab dan berkelanjutan mulai dari kegiatan pembenihan sampai dengan pembesarannya. Artinya, mutu benih merupakan salah satu faktor penentu keberhasilan usaha budidaya, sehingga dalam kegiatan usaha pembenihan harus menerapkan teknik pembenihan sesuai dengan Standar Nasional Indonesia (SNI) dan Standar
Operasional Prosedur (SOP), serta menerapkan manajemen mutu perbenihan yaitu Cara Pembenihan Ikan Yang Baik (CPIB) atau Good Hatchery Practices (GHP). Jumlah unit pembenihan yang telah lulus sertifikasi CPIB sampai dengan bulan Desember 2015 sebanyak 378 unit dengan jumlah sertifikat mencapai 498 sertifikat dari total unit pembenihan 30.659 unit di seluruh Indonesia dan 115 unit adalah pembenihan udang yang sebagian besar berada di Provinsi Sulawesi Selatan, yaitu 40 unit atau sekitar 34,78\% (DJPB, 2015). Berdasarkan penelitian yang dilakukan oleh Lasima (2012) tentang Tingkat penerapan manajemen mutu pada UMKM pembenihan udang di Jawa Timur menyatakan tingkat penerapan manajemen mutu pada pembenihan udang di Jawa Timur baik yang telah disertifikasi CPIB maupun yang belum disertifikasi berada di level cukup tinggi pada Statistical Quality Control, Quality Assurance dan Total Quality Management. Empat faktor dominan yang dapat memengaruhi kinerja perusahaan adalah efisiensi biaya, persentasi SDM dengan latar belakang pendidikan S1, persentase SDM yang mengikuti pelatihan per tahun dan persentasi keluhan pelanggan. Penelitian tentang penerapan CPIB di Sulawesi Selatan terutama di Kabupaten Barru belum banyak dilakukan, maka perlu dilakukan penelitian terkait kajian penerapan CPIB terhadap kinerja unit pembenihan udang di Kabupaten Barru. Tujuan penelitian ini: (1) mempelajari regulasi terkait CPIB; (2) menganalisis hubungan penerapan CPIB terhadap kinerja UMKM Pembenihan Udang di Kabupaten Barru; (3) mengukur kinerja UMKM Pembenihan Udang di Kabupaten Barru dan (4) mengidentifikasi gap penerapan CPIB.

\section{METODE PENELITIAN}

Penelitian dilaksanakan di Unit Pemenihan Udang Kabupaten Barru pada bulan November sampai Desember 2016. Responden yang dipilih untuk mengisi kuesioner dilakukan dengan metode sensus, yaitu teknik penentuan contoh bila 
semua anggota populasi digunakan sebagai contoh (Sugiyono, 2008).

Data penelitian ini meliputi data primer dan sekunder. Data primer diperoleh melalui kuesioner dan wawancara. Data sekunder adalah data penunjang, yang didapatkan dari instansi terkait, Peraturan Menteri Perikanan, studi pustaka dan dokumen lain yang berkaitan dengan penelitian ini. Pengolahan data menggunakan perangkat lunak Statistical Package for the Social Science (SPSS) 20.0 dan analisis data dilakukan dengan analis isi (content analyisis), analisis regresi liner berganda dan Importance Performance Analysis (IPA).

Analisis isi (content analysis) adalah penelitian yang bersifat pembahasan mendalam terhadap isi suatu informasi tertulis atau tercetak dalam media massa (Natasha, 2015). Menurut Dunn (2000), analisis kebijakan adalah suatu bentuk analisis yang menghasilkan dan menyajikan informasi sedemikian rupa sehingga memberi landasan bagi pembuat kebijakan dalam mengambil keputusan. Analisis kebijakan juga menghasilkan informasi yang ada hubungannya dengan kebijakan yang dapat dimanfaatkan untuk memecahkan masalah. Selain itu, analisis kebijakan juga menghasilkan informasi mengenai nilainilai dan arah tindakan yang lebih baik. Salah satu metode umum yang digunakan adalah analisis isi (content analysis). Analisis isi adalah suatu teknik untuk mengambil kesimpulan dengan mengidentifikasi karakteristik khusus suatu pesan secara objektif dan sistematis. Penyelidikan yang dilakukan dengan analisis ini meliputi pengumpulan informasi melalui pengujian arsip dan dokumen (Bungin, 2006). Analisis isi digunakan untuk menggambarkan sifat suatu keadaan yang sementara berjalan pada saat penelitian dilakukan dan mengidentifikasi sebab-sebab dari suatu gejala tertentu dari peraturan yang berlaku terkait kebijakan sertifikasi CPIB.

Analisis regresi merupakan salah satu teknik analisis data yang digunakan untuk mengkaji beberapa peubah dan meramal suatu peubah (Kutner et al., 2004). Menurut Usman, metode analisis regresi linear berganda, untuk menganalisis peubah independen terhadap peubah dependen (Zulkarnain et al., 2013). Analisis regresi linear berganda digunakan untuk menganalisis penerapan CPIB terhadap kinerja dan faktor-faktor dari aspek persyaratan CPIB yang paling berpengaruh terhadap kinerja UMKM Pembenihan Udang.
IPA digunakan untuk mengetahui peringkat berbagai unsur dari kumpulan jasa dan mengidentifikasi tindakan yang diperlukan, serta gap harapan dan kinerja unit pembenihan. Berdasarkan hasil penilaian tingkat kepentingan dan hasil penilaian kinerja akan menghasilkan tingkat kesesuaian antara kepentingan dan pelaksanaannya. Tingkat kesesuaian tersebut akan menentukan urutan prioritas peningkatan faktor yang memengaruhi kepuasan pelanggan (Dirgantara dan Sambodo, 2015). Pada IPA, dilakukan pemetaan menjadi empat kuadran untuk seluruh peubah yang memengaruhi mutu pelayanan. Strategi dilakukan sesuai dengan posisi masingmasing peubah pada keempat kuadran tersebut sebagai berikut (Simamora, 2002):

a. Kuadran 1 (Concentrate These) merupakan wilayah yang memuat faktor-faktor yang dianggap penting oleh pelanggan, tetapi pada kenyataannya faktor-faktor ini belum sesuai dengan harapan pelanggan (tingkat kepuasan yang diperoleh masih rendah). Peubah-peubah yang masuk dalam kuadran ini harus ditingkatkan.

b. Kuadran 2 (Keep Up The Good Work) merupakan wilayah yang memuat faktor-faktor yang dianggap penting oleh pelanggan dan faktorfaktor yang dianggap pelanggan sudah sesuai dengan yang diharapkan, sehingga tingkat kepuasannya relatif lebih tinggi. Peubahpeubah yang masuk dalam kuadran ini harus tetap dipertahankan karena semua peubah menjadikan produk atau jasa unggul di mata pelanggan.

c. Kuadran 3 (Low Priority) merupakan wilayah yang memuat faktor-faktor yang dianggap kurang penting oleh pelanggan, dan pada kenyatannya kinerjanya tidak terlalu istimewa. Peningkatan peubah-peubah yang termasuk dalam kuadran ini dapat dipertimbangkan kembali, karena pengaruhnya terhadap manfaat yang dirasakan oleh pelanggan sangat kecil.

d. Kuadran 4 (Possible Overkill) merupakan wilayah yang memuat faktror-faktor yang dianggap kurang penting oleh pelanggan, dan dirasakan terlalu berlebihan. peubah-peubah yang termasuk dalam kuadran ini dapat dikurangi sehingga perusahaan dapat menghemat biaya. 


\section{HASIL DAN PEMBAHASAN}

Hasil rekapitulasi menunjukkan data kuesioner dan wawancara yang lengkap dan dapat dikunjungi sebanyak 22 unit pembenihan, pemilik usaha berumur 35-44 tahun (50\%), 45-54 tahun (45\%) dan hanya satu pemilik yang berumur 25-34 tahun (5\%). Pendidikan terakhir pemilik usaha didominasi oleh SLTA/SMA/ sederajat sembilan orang (41\%), S1 enam orang $(27 \%)$, D3 tiga orang (14\%), dan SLTP/SMP tiga orang $(14 \%)$. Rataan jumlah karyawan yang bekerja dalam satu unit pembenihan adalah lima orang (termasuk 2 orang karyawan lepas), terdapat dua unit pembenihan yang hanya memiliki satu orang karyawan. Karyawan yang bekerja dalam unit pembenihan merupakan anggota keluarga atau kerabat dekat.

\section{Analisis Isi}

Peraturan yang dikaji dalam penelitian ini adalah Standar Nasional Indonesia (SNI) Cara Pembenihan Ikan yang Baik (CPIB), Pendekatan Hazard Analysis Critical Control Point (HACCP) tentang pembenihan udang, Peraturan Menteri Kelautan dan Perikanan Republik Indonesia Nomor 19 Tahun 2010 Tentang Pengendalian Sistem Jaminan Mutu dan Keamanan Hasil Perikanan, Peraturan Menteri Kelautan dan Perikanan Republik Indonesia No. 35 Tahun 2016 Tentang Cara Pembenihan Ikan yang Baik dan Keputusan Menteri Kelautan dan Perikanan Republik Indonesia Nomor 02 Tahun 2007 Tentang CBIB.

Penerapan SNI pada dasarnya bersifat sukarela. Tujuan disusunnya SNI CPIB menyediakan sebuah ketentuan tentang persayaratan teknis, manajemen, keamanan pangan dan lingkungan untuk diterapkan pada unit pembenihan skala kecil (unit pembenihan rakyat atau UPR dan hatchery skala rumah tangga atau HSRT) dan unit pembenihan skala besar (unit pelayanan teknis dan swasta) dalam memproduksi benih bermutu, membantu pelaku usaha pembenihan dalam meningkatkan daya saing produk benih yang dihasilkan sesuai tuntutan pasar, menjamin keberlangsungan usaha pembenihan, tahapan menuju harmonisasi dengan standar internasional dan menerapkan seluruh tahapan CPIB untuk menjaga konsistensi mutu benih. Standar ini meliputi persyaratan teknis, manajeman, keamanan pangan dan lingkungan.

HACCP adalah suatu alat (tools) yang digunakan untuk menilai tingkat bahaya, men- duga perkiraan risiko dan menetapkan ukuran yang tepat dalam pengawasan, dengan menitikberatkan pada pencegahan dan pengendalian proses dari pada pengujian produk akhir yang biasanya dilakukan dalam cara pengawasan tradisional. Pendekatan HACCP akan membantu perencanaan berbagai kegiatan keamanan makanan dan pendidikan kesehatan yang memusatkan perhatian pada berbagai bahaya yang berhubungan dengan jenis makanan yang dikonsumsi dan makanan yang diolah dan disiapkan (Ilmiawan et al., 2014). Pendekatan HACCP adalah sistem manajemen pencegahan risiko yang didasarkan pada analisis bahaya dan telah banyak digunakan untuk mengidentifikasi dan mengontrol risiko terhadap kesehatan manusia dalam sistem pengolahan makanan. Prinsip-prinsip HACCP telah diterapkan sebagai alat manajemen resiko untuk mengontrol virus patogen pada penelitian dan fasilitas produksi udang, yaitu: (1) melakukan analisis bahaya secara sistematis, (2) menentukan titik kontrol kritis, (3) membuat batas kritis, (4) menentukan perbaikan yang tepat, (5) membuat prosedur pemantauan, (6) mengembangkan prosedur verifikasi dan (7) merancang pembukuan rekaman (FAO, 2007).

Ruang lingkup Peraturan Menteri Nomor 19 Tahun 2010 meliputi pengaturan tentang pengorganisasian dan pelaksanaan pengendalian sistem jaminan mutu dan keamanan hasil perikanan pada setiap tahapan/proses produksi primer, budidaya dan tangkap, pengolahan dan distribusi hasil perikanan. Ruang lingkup Peraturan Menteri Kelautan dan Perikanan RI Nomor 35 Tahun 2016 meliputi kriteria dan persyaratan CPIB, cara pengajuan sertifikasi CPIB perubahan, perpanjangan, penggantian sertifikat CPIB dan pembinaan. Isi kriteria dan persyaratan CPIB sama dengan yang tertuang pada Pedoman Umum CPIB.

Pengertian CBIB dalam Keputusan Menteri Kelautan dan Perikanan RI No 02 Tahun 2007 adalah cara memelihara dan/atau membesarkan ikan serta memanen hasilnya dalam lingkungan yang terkontrol sehingga memberikan jaminan keamanan pangan dari pembudidayaan dengan memperhatikan sanitasi, pakan, obat ikan dan bahan kimia, serta bahan biologis. Tujuan sertifikasi CBIB adalah kemampuan telusur mulai dari benih, dari mana didapatkan, sampai pada produksi dan pengiriman ke konsumen. Ruang lingkup Keputusan Menteri Kelautan dan Perikanan RI No 02 Tahun 2007 meliputi keamanan pangan pada usaha pembesaran ikan, pengguna- 
an pakan ikan, obat ikan, pupuk, probiotik, desinfektan, dan bahan kimia lain, keamanan pangan pada saat panen, penanganan, dan pendistribusian hasil, verifikasi, tindakan koreksi dan pencatatan pada usaha pembudidayaan ikan, serta pengendalian.

Persyaratan jaminan mutu dan keamanan hasil perikanan harus diterapkan oleh setiap pelaku usaha perikanan baik perorangan maupun badan usaha termasuk koperasi yang melakukan kegiatan produksi, pengolahan dan distribusi. Ruang lingkup Keputusan Menteri Kelautan dan Perikanan No 52a Tahun 2013 tentang Persyaratan Jaminan Mutu dan Keamanan Hasil Perikanan Pada Proses Produksi, Pengolahan dan Distribusi, yaitu persyaratan jaminan mutu dan keamanan hasil perikanan yang harus dilakukan oleh pelaku usaha di bidang perikanan pada Kapal Penangkap Ikan dan Kapal Pengangkut Ikan, Tempat Pendaratan Ikan, Tempat Pemasaran Ikan, Unit Pembudidayaan Ikan, Unit Pengumpul, Unit Pengolahan Ikan dan Distribusi Hasil Perikanan. Persyaratan keamanan pangan dalam unit pembenihan ikan harus menggunakan benih yang berasal dari unit pembenihan bersertifikat CPIB atau sudah menerapkan SNI.

Berdasarkan enam peraturan yang terkait dengan pembenihan udang pada Keputusan Menteri Kelautan dan Perikanan RI No 02 Tahun 2007 dan Keputusan Menteri Kelautan dan Perikanan No 52a Tahun 2013 memiliki syarat benih yang digunakan berasal dari unit pembenihan udang bersertifikat CPIB. Kedua peraturan tersebut tidak menyatakan apabila benih tidak berasal dari unit pembenihan yang telah bersertifikat tidak dapat dilanjutkan sertifikasi (critical point) CBIB atau dijual bebas dan tidak adanya sanksi apabila benih yang tidak bersertifikat beredar bebas. Sampai saat ini, tidak ada keharmonisan peraturan yang berisi mengenai kewajiban setiap pembudidaya atau pembenih ikan, khususnya komoditas udang harus melakukan sertifikasi, sehingga mutu benih yang beredar dapat terkendali. Ketidakharmonisan regulasi yang ada saat ini menyebabkan pembenih budidaya tidak peduli dengan mutu benih udang yang dihasilkan dan tidak konsisten terhadap penerapan CPIB yang dikarenakan hanya fokus terhadap jumlah produksi untuk mencukupi permintaan pasar dan keuntungan.

\section{Analisis Regresi Linear Berganda}

Hasil analisis regresi linear berganda menunjukkan persamaan sebagai berikut:

\section{$\mathrm{Y}=1.934+0.098 \mathrm{X}_{1}+0.006 \mathrm{X}_{2}+0.649 \mathrm{X}_{3}+1.211 \mathrm{X}_{4}+\mathrm{e}$}

Persamaan tersebut dapat diartikan bahwa peubah teknis, manajemen, keamanan pangan dan lingkungan berpengaruh positif terhadap kinerja. Peubah yang dominan memengaruhi kinerja unit pembenihan udang adalah keamanan pangan. Berdasarkan uji nyata parsial (uji t) diperoleh aspek keamanan pangan dan lingkungan berpengaruh nyata terhadap kenaikan atau penurunan kinerja. Aspek keamanan pangan yang dipersyaratkan dan diterapkan dalam CPIB meliputi (1) sumber air yang bebas dari pencemaran logam berat $(\mathrm{Cd}, \mathrm{Hg}$ dan $\mathrm{Pb})$ dan bakteri E.coli. (2) Penerapan biosekuriti dan sarana biosekuriti yang layak dan (3) penggunaan obat ikan dan bahan kimia yang harus terdaftar di Kementerian Kelautan dan Perikanan, serta penggunaan yang sesuai dengan peruntukannya. Aspek lingkungan meliputi dua hal yang terdiri atas sanitasi lingkungan yang baik dan melakukan pengolahan limbah sebelum dibuang ke perairan umum (DJPB 2015). Hal tersebut dilihat dari nilai $p$ value (sig) lebih kecil dari taraf nyata $5 \%(0,05)$ dan thitung $>$ tabel kemananan pangan $(2,733>2,109)$ dan lingkungan $(2,670>$ 2,109). Aspek teknis dan manajemen tidak memiliki pengaruh nyata terhadap naik atau turunnya kinerja, karena nilai $p$ value (sig) lebih besar dari 0,05 dan nilai thitung $<$ tabel. Hasil perhitungan koefisien determinasi (Adjusted $R$ Square) 0,562. Hal ini menunjukan persyaratan teknis, manajemen, keamanan pangan dan lingkungan mampu menjelaskan kinerja 56,2\%, serta sisanya $(43,8 \%)$ dijelaskan oleh peubah lain yang tidak diteliti dalam penelitian ini.

\section{Analisis Kepentingan-Kinerja}

Atribut yang memiliki nilai kesesuaian paling rendah merupakan kinerja yang harus menjadi perhatian utama. Nilai kesesuaian diperoleh dengan membandingkan skor penilaian kinerja dengan skor harapan tiap atribut. Kinerja yang mendapatkan nilai paling baik adalah tersedianya perlengkapan produksi yang memadai. Kinerja yang paling utama untuk diperbaiki oleh unit pembenihan udang adalah "mampu melengkapi rekaman sebagai bukti pekerjaan telah dilakukan sesuai SOP." Hasil perhitungan nilai kesesuaian dapat dilihat pada Tabel 1. 
Tabel 1. Nilai kesesuaian kinerja unit pembenihan udang

\begin{tabular}{lccc}
\hline \multicolumn{1}{c}{ Atribut } & \multicolumn{2}{c}{ Skala Pengukuran } & Tingkat Ke- \\
\cline { 2 - 3 } sesuaian (\%)
\end{tabular}

Tabel 2 menunjukkan satu atribut yang dinilai auditor CPIB terhadap kinerja unit pembenihan untuk memenuhi kepuasan pelanggan memiliki nilai positif, yaitu perlengkapan produksi dalam unit pembenihan dianggap sudah sesuai harapan. Nilai negatif antara rataan kinerja dengan harapan memiliki arti bahwa seluruh kinerja unit pembenihan belum sesuai harapan auditor CPIB dalam menerapkan prinsip-prinsip CPIB dan memenuhi kepuasan pelanggan. Hampir seluruh unit pembenihan tidak menggunakan pakaian kerja saat dalam ruang produksi, karena pegawai unit pembenihan menganggap pakaian kerja tidak berpengaruh nyata terhadap kinerja produksi maupun tidak disediakannya pakaian kerja dalam ruang produksi. Sarana dan prasarana dalam unit pembenihan dinilai tidak memenuhi standar, karena beberapa mesin tidak berfungsi/rusak dan ketersediaan listrik yang digantikan dengan genset.

Sanitasi lingkungan pembenihan tidak baik, karena banyaknya sampah plastik, organik dan puntung rokok dalam area produksi yang berasal dari pemilik, pegawai, maupun tamu. Hal itu disebabkan tidak adanya tempat sampah dan ketegasan ataupun kesadaran pemilik/pegawai pembenihan dalam menjaga lingkungan yang bersih. Kesediaan pimpinan dan pegawai dalam menangani keluhan pelanggan dianggap belum memuaskan, karena hampir seluruh keluhan pelanggan mengenai mutu benih atau kematian benih tidak dicatat dalam rekaman. Nilai gap negatif yang paling utama dijadikan perhatian adalah kelengkapan rekaman, seluruh pegawai unit pembenihan udang mengeluhkan sistem pendokumentasian yang masih manual dengan alasan tidak ada waktu, letih, menunda dan akhirnya tidak dicatat. Hal lain yang paling mendasar adalah unit pembenihan tidak menerapkan CPIB secara konsisten, seperti dikemukakan sebelumnya bahwa tidak adanya perbedaan harga antara benih bersertifikat atau tidak bersertifikat, sehingga pembenih merasa terpacu bukan karena kesadaran mutu, tetapi lebih kepada meningkatkan jumlah produksi benih untuk meningkatkan penjualan dan memenuhi permintaan pasar.

Strategi yang dapat dilakukan sesuai posisi masing-masing peubah pada keempat kuadran tersebut dijelaskan pada Gambar 1.

a. Kuadran 1 (Concentrate These) merupakan wilayah yang memuat faktor-faktor yang dianggap penting, tetapi pada kenyataannya faktor-faktor ini belum sesuai dengan harapan (tingkat kepuasan yang diperoleh masih rendah). Peubah-peubah yang masuk dalam kuadran ini harus ditingkatkan. Atribut yang termasuk dalam kuadran ini adalah mampu melengkapi rekaman sebagai bukti pekerjaan telah dilakukan sesuai SOP, menerapkan prinsip CPIB secara konsisten, kesadaran mutu pegawai dan pimpinan, serta profesionalisme dan loyalitas pegawai dalam bekerja. 
Tabel 2. Gap kinerja dengan harapan

\begin{tabular}{lcccc}
\hline \multicolumn{1}{c}{ Atribut } & Skala Pengukuran & \multirow{2}{*}{ Gap } & Keterangan \\
\cline { 2 - 4 } & Kinerja & Harapan & & \\
\hline Penggunaan pakaian kerja pegawai & 2.50 & 3.30 & -0.80 & Tidak Puas \\
Profesionalisme dan loyalitas pegawai dalam bekerja & 3.40 & 4.80 & -1.40 & Tidak Puas \\
Sarana dan prasarana (fasilitas) dalam unit pembenihan yang memadai & 3.70 & 4.80 & -1.10 & Tidak Puas \\
Perlengkapan produksi dalam unit pembenihan yang lengkap dan memadai & 4.80 & 4.80 & 0 & Puas \\
Sanitasi lingkungan pembenihan & 3.40 & 4.50 & -1.10 & Tidak Puas \\
Koordinasi yang baik antara pegawai dan pimpinan & 4.000 & 4.70 & -0.70 & Tidak Puas \\
Kesadaran mutu pegawai dan pimpinan & 3.400 & 5.00 & -1.60 & Tidak Puas \\
Perhatian terhadap saran dan kritik yang diberikan oleh pelanggan & 3.500 & 4.60 & -1.10 & Tidak Puas \\
Komitmen pimpinan puncak terhadap mutu & 3.800 & 5.00 & -1.20 & Tidak Puas \\
Mengikuti perkembangan atau perubahan yang berkaitan dengan inovasi teknologi & 3.20 & 4.50 & -1.30 & Tidak Puas \\
atau metode pembenihan & & & & \\
Kesediaan pimpinan dan pegawai dalam menangani keluhan pelanggan & 3.50 & 4.70 & -1.20 & Tidak Puas \\
Kesediaan pimpinan dan pegawai memberikan informasi terkait pembenihan kepada & 3.10 & 4.40 & -1.30 & Tidak Puas \\
pelanggan & & & & \\
Menerapkan prinsip CPIB secara konsisten & 3.20 & 5.00 & -1.80 & Tidak Puas \\
Mampu melengkapi rekaman sebagai bukti pekerjaan telah dilakukan sesuai SOP & 2.80 & 5.00 & -2.20 & Tidak Puas \\
Mampu merencanakan dan mengorganisir kerja secara efektif & 3.90 & 4.60 & -0.70 & Tidak Puas \\
Memperbaiki ketidaksesuaian saat survailen CPIB & 4.00 & 4.90 & -0.90 & Tidak Puas \\
Pimpinan dan pegawai memiliki pengetahuan dan memahami prinsip CPIB & 3.60 & 5.00 & -1.40 & Tidak Puas \\
Pimpinan dan pegawai memiliki pengetahuan mengenai prosedur sertifikasi dan & 3.00 & 4.60 & -1.60 & Tidak Puas \\
survailen CPIB & & & & \\
Pimpinan dan pegawai memiliki pengetahuan dan memahami SPO dalam unit & 3.60 & 4.60 & -1.00 & Tidak Puas \\
pembenihan & & & & \\
\hline
\end{tabular}

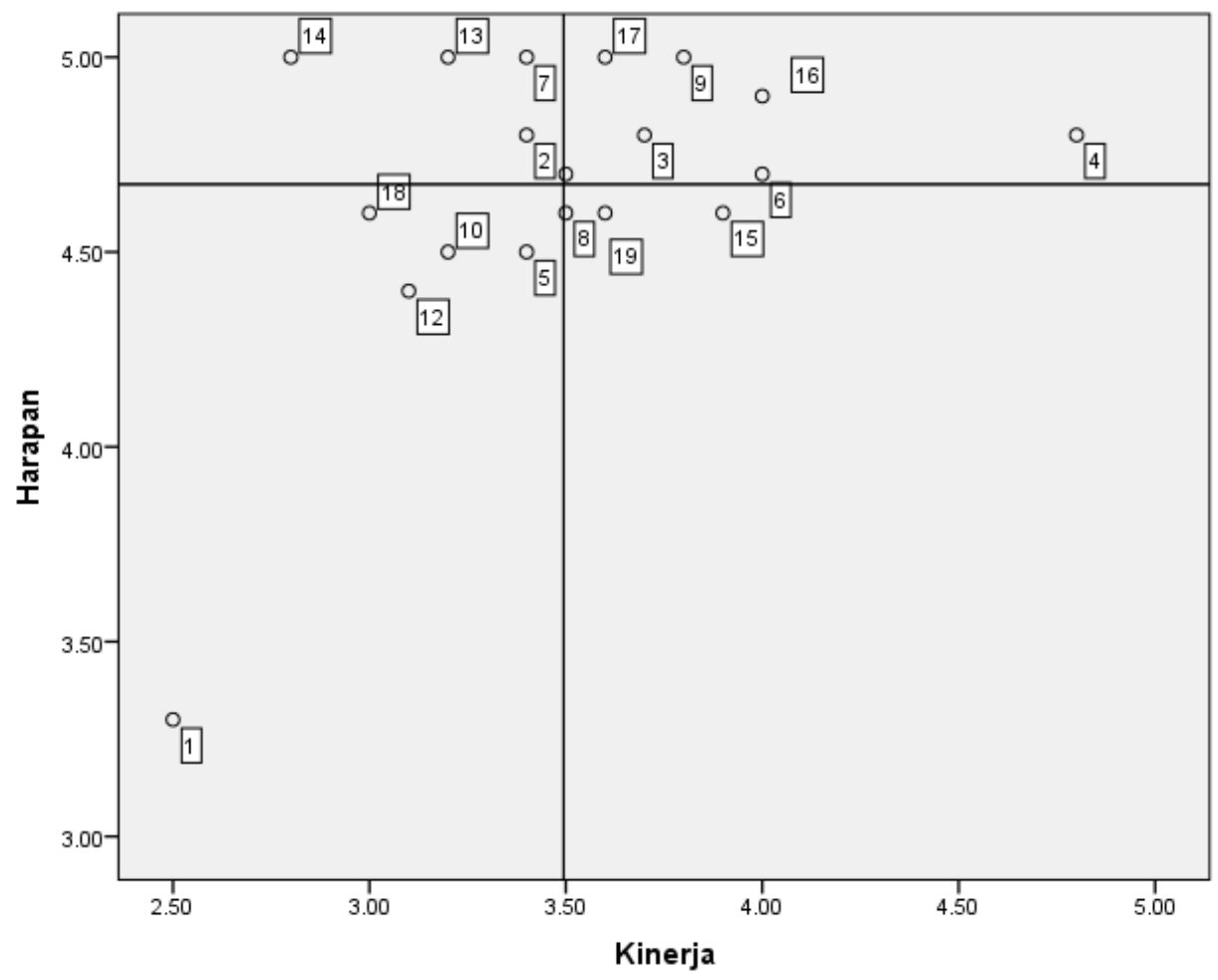

Gambar 1. Pemetaan hasil kinerja dan harapan

b. Kuadran 2 (Keep Up The Good Work) merupakan wilayah yang memuat faktor-faktor yang dianggap penting oleh pelanggan dan faktorfaktor yang dianggap pelanggan sudah sesuai dengan harapan sehingga tingkat kepuasannya relatif lebih tinggi. peubah-peubah yang masuk dalam kuadran ini harus tetap dipertahankan, karena semua peubah ini menjadikan produk atau jasa unggul di mata pelanggan. Atribut yang termasuk dalam kuadran ini adalah pimpinan, pegawai memiliki pengetahuan dan memahami prinsip 
CPIB, serta komitmen pimpinan puncak terhadap mutu, sarana dan prasarana (fasilitas) dalam unit pembenihan yang memadai, memperbaiki ketidaksesuaian saat survailen CPIB, perlengkapan produksi dalam unit pembenihan yang lengkap dan memadai dan koordinasi yang baik antara pegawai dan pimpinan.

c. Kuadran 3 (Low Priority) merupakan wilayah yang memuat faktor-faktor yang dianggap kurang penting dan pada kenyatannya kinerjanya tidak terlalu istimewa. Peningkatan peubah-peubah yang termasuk dalam kuadran ini dapat dipertimbangkan kembali karena pengaruhnya terhadap manfaat yang dirasakan oleh pelanggan sangat kecil. Atribut yang termasuk dalam kuadran ini adalah pimpinan, pegawai memiliki pengetahuan mengenai prosedur sertifikasi dan survailen CPIB, mengikuti perkembangan atau perubahan yang berkaitan dengan inovasi teknologi atau metode pembenihan, kesediaan pimpinan dan pegawai memberikan informasi terkait pembenihan kepada pelanggan dan sanitasi lingkungan pembenihan.

d. Kuadran 4 (Possible Overkill) merupakan wilayah yang memuat faktor-faktor yang dianggap kurang penting dan dirasakan terlalu berlebihan. peubah-peubah yang termasuk dalam kuadran ini dapat dikurangi agar perusahaan dapat menghemat biaya. Atribut yang termasuk dalam kuadran ini adalah pimpinan, pegawai memiliki pengetahuan dan memahami SOP dalam unit pembenihan, perhatian terhadap saran dan kritik yang diberikan oleh pelanggan dan mampu merencanakan dan mengorganisir kerja secara efektif.

\section{Perbandingan Rataan Produksi}

Analisis rataan produksi dilakukan untuk mengetahui peningkatan kinerja dalam unit pembenihan sebelum dan sesudah sertifikasi CPIB. Hasil perhitungan rataan produksi dapat dilihat pada Tabel 3.

Data produksi yang diajukan saat sertifikasi adalah rekapitulasi data produksi satu tahun sebelum mengajukan sertifikasi. Diantara 22 unit pembenihan udang yang menjadi responden penelitian ini teridentifikasi dua unit $(9,09 \%)$ tidak mengalami kenaikan atau penurunan produksi, 13 unit $(59,09 \%)$ yang mengalami kenaikan produksi dan tujuh unit $(31,82 \%)$ mengalami penurunan produksi. Persentase rataan kenaikan produksi UPU dari sebelum melakukan sertifikasi sampai pada tahun 2015 adalah 19\%.

Tabel 3. Produksi unit pembenihan setelah sertifikasi

\begin{tabular}{|c|c|c|c|c|}
\hline Nama Unit Pembenihan & $\begin{array}{c}\text { Produksi Awal Sertifikasi } \\
\text { (Ekor/Tahun) }\end{array}$ & $\begin{array}{c}\text { Produksi Tahun } 2015 \\
\text { (Ekor/Tahun) }\end{array}$ & $\begin{array}{c}\text { Selisih } \\
\text { (Ekor/Tahun) }\end{array}$ & $\begin{array}{c}\text { Persentase } \\
(\%)\end{array}$ \\
\hline UD Windu Asyura Raya & 7.000 .000 & 5.000 .000 & -2.000 .000 & -40 \\
\hline Ezhar Benur & 6.000 .000 & 6.000 .000 & - & 0 \\
\hline Rezky Bersama & 12.000 .000 & 12.800 .000 & 800.000 & 6 \\
\hline Naufa Benur & 7.000 .000 & 8.000 .000 & 1.000 .000 & 13 \\
\hline UD Halim Asri Bahari & 6.000 .000 & 6.000 .000 & - & 0 \\
\hline Windu Pasifik & 1.000 .000 & 3.000 .000 & 2.000 .000 & 67 \\
\hline UD Sippurenu Benur & 11.000 .000 & 4.000 .000 & -7.000 .000 & -175 \\
\hline Nadia Benur & 7.000 .000 & 15.000 .000 & 8.000 .000 & 53 \\
\hline Arkan Benur & 10.000 .000 & 18.000 .000 & 8.000 .000 & 44 \\
\hline Armina Benur & 600.000 & 2.000 .000 & 1.400 .000 & 70 \\
\hline Nurrahmat Benur Palie & 8.000 .000 & 10.000 .000 & 2.000 .000 & 20 \\
\hline Aldi Putra Benur & 7.000 .000 & 5.000 .000 & -2.000 .000 & -40 \\
\hline Bintang Benur & 12.000 .000 & 4.000 .000 & -8.000 .000 & -200 \\
\hline UD Sinar Benur Lembae & 9.000 .000 & 3.000 .000 & -6.000 .000 & -200 \\
\hline UD Cakra Buana Monodon & 7.000 .000 & 5.000 .000 & -2.000 .000 & -40 \\
\hline UD Terang Abadi Benur & 7.000 .000 & 5.000 .000 & -2.000 .000 & -40 \\
\hline UD Windu Sinar Mas & 4.000 .000 & 7.000 .000 & 3.000 .000 & 43 \\
\hline Rezqi Benur Mandiri & 6.000 .000 & 12.000 .000 & 6.000 .000 & 50 \\
\hline Alifah Benur & 800.000 & 6.000 .000 & 5.200 .000 & 87 \\
\hline Benur Afiat & 4.500 .000 & 25.000 .000 & 20.500 .000 & 82 \\
\hline UD Anugerah Bumi Hero & 25.000 .000 & 30.000 .000 & 5.000 .000 & 17 \\
\hline Benur Bahari & 3.000 .000 & 7.000 .000 & 4.000 .000 & 57 \\
\hline Rataan Keseluruhan & 7.313 .636 & 9.036 .364 & 1.722 .727 & 19 \\
\hline
\end{tabular}




\section{Implikasi Manajerial}

Implikasi manajerial yang perlu diaplikasikan dalam unit pembenihan udang di Kabupaten Barru adalah:

a. Konsisten dalam menerapkan CPIB karena tantangan dan peluang saat ini dan ke depan adalah konsumen semakin sadar tentang mutu dan dapat bersaing dalam perdagangan bebas.

b. Memperluas pemasaran dengan memanfatkan teknologi informasi (internet dan sosial media).

c. Melakukan studi banding ke unit pembenihan yang telah sukses dan berkembang dalam segi produksi dan pemasaran.

d. Meningkatkan kompetensi karyawan mengenai teknologi atau cara terbaru dalam produksi benih udang yang efektif dan efisien melalui pelatihan.

\section{KESIMPULAN}

Hasil analisis isi (content analysis) didapatkan tidak adanya regulasi mengenai kewajiban seluruh pembudidaya untuk menggunakan benih yang telah disertifikasi, benih yang belum disertifikasi masih dapat dijual bebas dan tidak ada perbedaan harga maupun perlakuan terhadap benih yang telah disertifikasi, serta penerapan SNI CPIB yang masih bersifat sukarela. Penerapan CPIB memiliki pengaruh positif terhadap kinerja unit pembenihan udang di Kabupaten Barru. Faktor yang paling memengaruhi kinerja pada unit pembenihan udang di Kabupaten Barru adalah keamanan pangan dan lingkungan.

Kinerja yang perlu diperbaiki oleh pemilik unit pembenihan udang di Kabupaten Barru adalah melengkapi rekaman sebagai bukti pekerjaan telah dilakukan sesuai SOP. Kinerja yang dinilai paling baik adalah tersedianya perlengkapan produksi yang memadai untuk menunjang kegiatan produksi. Hasil rataan produksi setelah menerapkan prinsip CPIB menunjukkan adanya peningkatan kinerja produksi $19 \%$. Tingkat kesesuaian antara harapan dan kinerja pada unit pembenihan untuk memenuhi kepuasan pelanggan dan konsistensi penerapan CPIB memiliki nilai gap negatif $-1.18 \%$, seluruh kinerja unit pembenihan belum memenuhi kepuasan pelanggan dan tidak konsisten menerapkan prinsip-prinsip CPIB.

\section{DAFTAR PUSTAKA}

[BSN] Badan Standardisasi Nasional. 2014. Cara Pembenihan Ikan yang Baik. Jakarta (ID): BSN.

Bungin, B. 2006. Metodologi Penelitian Kualitatif. Aktualisasi Metodologis Ke Arah Ragam Varian Kontemporer. Jakarta (ID): PT. Raja Grafindo Persada.

[DJPB] Direktorat Jenderal Perikanan Budidaya. 2015. Pedoman Sertifikasi CPIB. Jakarta (ID): DJPB.

Dirgantara, HB., AT. Sambodo. Penerapan Model Importance Performance Analysis dalam Studi Kasus: Analisis Kepuasan Konsumen Bhineka.com. Jurnal Sains dan Teknologi Kalbi Scientia. 2(1): 52-62.

Dunn, WN. 2000. Pengantar Analisis Kebijakan Publik. Ed. Ke-2. Samodra, dkk, Penerjemah. Yogyakarta (ID): Gadjah Mada University Press. Terjemahan dari: Public Policy Analysis.

[FAO] Food and Agriculture Organization. 2007. Improving Penaeus monodon Hatchery Practices. Manual Based on Experience In India. Roma (IT): Food And Agriculture Organization Of The United Nations.

Ilmiawan, N., S. Astuti, O. Nawansih. 2014. Penggabungan penerapan sistem jaminan mutu ISO 9001:2008 dan sistem haccp ke dalam sistem manajemen keamanan pangan ISO 22000:2009 (studi kasus di PT Indokom Samudra Persada).Jurnal Teknologi dan Industri Hasil Pertanian. 19(3):229-242.

Kementerian Kelautan dan Perikanan. 2010. Keputusan Menteri Kelautan dan Perikanan Nomor 02 Tahun 2007 Tentang Cara Budidaya Ikan yang Baik. Jakarta (ID): Kementerian Kelautan dan Perikanan.

Kementerian Kelautan dan Perikanan. 2013. Keputusan Menteri Kelautan dan Perikanan Nomor 52a Tahun 2013 Tentang Persyaratan Jaminan Mutu dan Keamanan Hasil Perikanan Pada Proses Produksi, Pengolahan Dan Distribusi. Jakarta (ID): Kementerian Kelautan dan Perikanan.

Kementerian Kelautan dan Perikanan. 2010. Peraturan Menteri Kelautan dan Perikanan Nomor 19 Tahun 2010 Tentang Pengendalian Sistem Jaminan Mutu dan Keamanan Hasil Perikanan. Jakarta (ID): Kementerian Kelautan dan Perikanan.

Kementerian Kelautan dan Perikanan. 2016. Peraturan Menteri Kelautan dan Perikanan 
Nomor 35 Tahun 2016 Tentang Cara Pembenihan Ikan yang Baik. Jakarta (ID): Kementerian Kelautan dan Perikanan.

Kutner, MH., CJ. Nachtsheim, J. Neter. 2004. Applied Linear Regression Models. 4th ed. New York (US): McGraw-Hill Companies, Inc.

Lasima, W., M. Syamsun, D. Kadarisman. 2012. Tingkat Penerapan Manajemen Mutu pada UMKM Pembenihan Udang di Jawa Timur. Jurnal Manajemen IKM. 7 (2): 143-151.

Natasha, G. 2015. Analisis isi rubrik "Indonesiabanget" pada majalah gogirl! Tahun 2013 tentang tradisi di Indonesia [internet]. EJournal Ilmu Komunikasi. 3(3): 617-627. [Diunduh 2017 April 06]. Tersedia pada: http://ejournal.ilkom.fisipunmul.ac.id/site/ wpcontent/uploads/2015/09/Jurnal\%20\%20 (09-21-15-04-57-24).pdf.
Nour, MT. 2014. Implementasi Kebijakan Cara Pembenihan Ikan yang Baik (CPIB) di Kabupaten Barru [Tesis]. Makassar (ID): Universitas Muslim Indonesia.

Simamora, B. 2002. Panduan Riset Perilaku Konsumen. Jakarta (ID): PT. Gramedia Pustaka Utama.

Sugiyono. 2008. Metode Penelitian Kunatitatif Kualitatif dan RED. Bandung (ID): Alfabet.

Zulkarnain, M., P. Purwanti, E. Indrayani. 2013. Analisis Pengaruh Nilai Produksi Perikanan Budidaya Terhadap Produk Domestik Bruto Sektor Perikanan di Indonesia. Jurnal ECSOFim. 1(1): 52-68. 